\title{
Spatial environmental risk evaluation of potential toxic elements in stream sediments
}

\author{
I. M. H. R. Antunes $\cdot$ M. T. D. Albuquerque $\cdot$ N. Roque
}

Received: 30 January 2018/ Accepted: 8 May 2018

(C) Springer Science+Business Media B.V., part of Springer Nature 2018

\begin{abstract}
Potential toxic elements (PTE), in stream sediments, were used as contamination indicators for the definition of high-/low-grade spatial clusters in the Monfortinho area (Central Portugal). A set of 271 stream sediment samples was used for spatial modelling and further definition of rings of enrichment—high and low rings. A three-step multivariate statistical and geostatistical approach was used: (1) principal components analysis for PTE's association evaluation and dimensionality reduction; (2) ordinary kriging as an unbiased interpolator for content inference and construction of a continuous representation of the considered attributes, at any arbitrary spatial location; (3) G clustering algorithm for the definition of high and low significance clusters. A moderate contamination in stream sediments is observed for almost all the considered PTE and a very high contamination for $\mathrm{Ba}, \mathrm{Cr}$ and $\mathrm{B}$. High contamination
\end{abstract}

I. M. H. R. Antunes and M. T. D. Albuquerque have equally contributed to the study.

I. M. H. R. Antunes ( $\square)$

ICT/University of Minho, CERENA/University of Lisbon,

Campus de Gualtar, Braga, Portugal

e-mail: imantunes@dct.uminho.pt

M. T. D. Albuquerque

Instituto Politécnico de Castelo Branco, CERENA/

University of Lisbon, Lisbon, Portugal

N. Roque

Instituto Politécnico de Castelo Branco, Castelo Branco,

Portugal clusters are observed for $\mathrm{Fe}, \mathrm{Ni}, \mathrm{Ba}, \mathrm{Cu}, \mathrm{B}, \mathrm{Zn}, \mathrm{V}-$ northwest and southeast clusters - and for $\mathrm{Cr}$ - north and southwest clusters. The contamination degree index varies from moderate to high, which is mainly associated with the old mineralizations. The high computed rings often overlap the areas of abandoned $\mathrm{Ba}-\mathrm{Zn}$ mineralization, as well as the sedimentary gold concentrations, along the Erges River banks. Tin and $\mathrm{Cd}$ spatial distribution may be related to former cassiterite exploitations in the survey area. Chromium is possibly connected with the schists. The definition of clusters with a PTE spatial enrichment will allow for the identification of contamination activities and therefore, the definition of adequate monitoring and mitigation actions.

Keywords Stream sediments - Contamination factor - Contamination degree $\cdot$ Principal components analysis · Ordinary kriging $\cdot \mathrm{G}$ clustering

\section{Introduction}

The occurrence of potential toxic elements (PTE) in a river system is determined by different factors such are geology, mineralogy, hydrology, botany, chemical reactivity, land use pattern and biological productivity (Albanese et al. 2013). These elements entering surface waters from natural or anthropogenic sources become part of the water suspension and the sediment system by absorption, precipitation and ion exchange 
processes (e.g. Jain and Sharma 2001; Abreu et al. 2008; Antunes et al. 2016).

Contaminants in river systems can be investigated by analysing either the water and the suspended material or the sediments. However, contaminants in water and suspended material could be influenced by water discharge fluctuations and low residence times (Singh et al. 1997). The geochemistry of stream sediments will be a good tool to evaluate the degree of trace elements contamination, due to their long residence time and the contents being naturally above detection limits (e.g. Bertin and Bourg 1995; Antunes et al. 2016).

The studies of stream sediments have widely become a key of subject interest in research on aquatic systems and environmental assessment, reflecting their quality and providing information on anthropogenic impacts (e.g. urbanization, industrialization, mining activities) (e.g. Baptista Neto et al. 2000; Dauvalter and Rognerud 2001; Santos et al. 2002; Woitke et al. 2003; Alexakis 2011; Romic et al. 2012; Chen et al. 2016; Tzoraki et al. 2015; GonzálezFernández et al. 2018). Under changing environmental conditions, sediments bounding PTE may be remobilized and added to the water or food chain; surface sediments act both as carriers and traps, catching pollutants and becoming possible sources of contaminants in the system (Chapman and Wang 1999). The fate and transport processes affect the behaviour of PTE in a river system, so it is crucial to outline these processes to better understand the nature-anthropogenic or geogenic - of the contaminating sources and to assess the environmental risk to ecosystems and human health (Zheng et al. 2008; Neiva et al. 2014, 2015).

Stream sediment also remains a common geochemical approach used for regional gold exploration (Fletcher 1997; Darwish and Poellmann 2010; Goovaerts et al. 2014, 2016). The exploration of sedimentary gold (alluvial) has occurred in distinct mineralized areas and is linked up with different genetic deposits (Townley et al. 2003; Chapman and Mortensen 2006; McInnes et al. 2008). PTE associated with gold exploitation-including $\mathrm{Cu}, \mathrm{Zn}, \mathrm{Sn}, \mathrm{W}, \mathrm{Cr}$, $\mathrm{Cd}, \mathrm{As}$ and $\mathrm{Pb}$ - can be dispersed downstream due to weathering processes. The extended and degree of PTE contamination associated to mineralization is variable, depending upon chemical characteristics and associated metals, and could influence nearby residential/agricultural land, stream sediments and streams (Ferreira da Silva et al. 2004; Antunes et al. 2016; Carvalho et al. 2016).

Geochemical mapping, historically used to enhance the interpretation of metal distribution patterns in mineral exploration, has recently become essential in environmental studies (Plant et al. 2001; Antunes and Albuquerque 2013; Antunes et al. 2014; Goovaerts et al. 2016). Understanding the geochemical processes that control precipitation and dissolution of secondary minerals in abandoned or active mines is crucial for the elaboration of models to predict the environmental impact of such sites (Gieré et al. 2003).

The main subject of this paper is the investigation of PTE geochemical distribution in the stream sediments of the Monfortinho area to assess the ecological risk associated with the old gold explorations developed in this area.

\section{Study area}

The study area is in the Monfortinho region, about $70 \mathrm{~km}$ east of Castelo Branco, Central Portugal. The area belongs to the tin-tungsten sector located in the Central Iberian Zone (CIZ) of the Iberian Massif, in the Portuguese-Spanish border (Fig. 1a). The Monfortinho area is occupied by the Cambrian schistmetagreywacke complex, which consists of alternating metapelites and metagreywackes with metaconglomerate and marble intercalations (Antunes et al. 2009). NW-SE Ordovician quartzites occur in the Cambrian schist-metagreywacke complex and the Tertiary sedimentary materials cover entirely the area (Oliveira et al. 1992).

Gold in Idanha-a-Nova region was widely exploited since the Roman period, especially in the areas of Rosmaninhal, Salvaterra do Extremo and Monfortinho, as demonstrated by the archaeological artifacts found along the region (Batata 2006). The Erges River terraces are divided into six levels, where the four most recent (between 5 and $45 \mathrm{~m}$ ) were exploited by the Romans for gold (Schwarz 1933). The remains of this old exploitations are still visible in some places, including fronts disassemble, sterile dump mines, supply channels and water tank accumulation. Most traces of operating fronts and other mining structures were changed by urban buildings from the late 1930s (Batata 2006). In the Monfortinho area, a daily exploitation of $2-4 \mathrm{~g} \mathrm{Au}$ and finding $\mathrm{Au}$ 

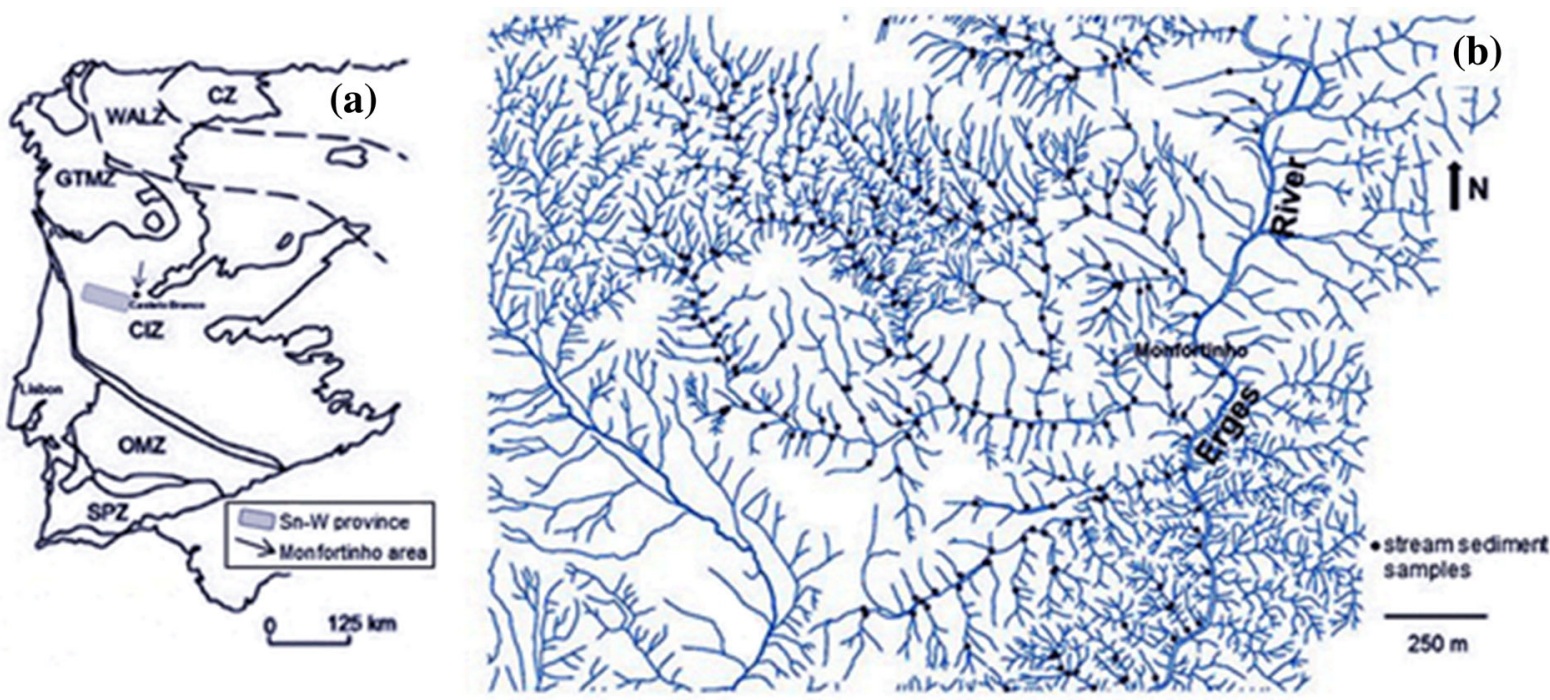

Fig. 1 a Location of the Monfortinho area in the Central Iberian Zone (CIZ); b Erges River hydrographic network with the location of the collected stream sediment samples

nuggets of 30-40 g have been reported. After 1933, other geological resources overlapped the Au mining activities, such are hot spring waters. In the late 1980s, the ore characteristics of the area were evaluated with prospecting studies, for the extraction of $484 \mathrm{~kg}$ of gold (Batata 2006).

The area is included in the basin of Erges River, a tributary of the right bank of the Tagus River. The Erges River has a permanent character waterline, with a flow having strong seasonal fluctuations. The Erges River delimits the transboundary of the PortugueseSpain border, and is one of the last wild rivers in Portugal with a rare natural value due to its geodiversity and mining landscape features.

The survey area surrounds the old sedimentary gold mining area, in the banks of the Erges River. Around the mine tailings, the mineralogical content is driven from the inert materials present in the gangue. The geochemical anomalies found, near tailings and mineralized areas, indicate the natural process of dominant winds and subsequent transport of fine dust, from the superficial layers of the heap (Santos Oliveira et al. 1998).

The northern area of Monfortinho shows an extremely vigorous geomorphology, with the highest altitudes around $600 \mathrm{~m}$, occurring in the quartzites, and the lowest ones, around $240 \mathrm{~m}$, located in alluvial materials on the Erges River. Agriculture is the main local economic activity with the steep sides mainly covered by pinus and eucalyptus. The thermal waters of low enthalpy-Fonte Santa spring-have a noteworthy contribution to the economic system and tourist activities in the area. This area is characterized by a dry climate and intermittent streams drying up in the summer (Antunes et al. 2002).

\section{Materials and methods}

Sample collection and preparation

The selected sampling site is included in the Erges river watershed (approximately $140 \mathrm{~km}^{2}$ ), surrounding the exploited sedimentary gold exploitations. The stream sediments are a result of the bedrock physical and chemical alteration and ulterior mobilization, transport and deposition along the river banks.

A total of 271 representative stream sediment samples (Fig. 1b) were collected in a narrow region, ranging from $50 \mathrm{~m}$ upstream to $100 \mathrm{~m}$ downstream from the streams' confluences, avoiding, wherever possible, the assemblage of organic matter (Instituto Geológico e Mineiro 1988).

All the samples were collected on the schistmetagreywacke complex, stored in polyethylene bags, and transported to the laboratory of INETI ( $S$. Mamede, Portugal). The samples went through a preparation procedure, including dry sieving at $40{ }^{\circ} \mathrm{C}$, 
disaggregation and homogenization. Finally, all the material was sieved through a $<200$ mesh screen. The $<250 \mu \mathrm{m}$ fraction was digested with aqua regia $\left(3: 1 \mathrm{HCl}-\mathrm{HNO}_{3}\right)$ and used for the determination of As, $\mathrm{B}, \mathrm{Ba}, \mathrm{Cd}, \mathrm{Cu}, \mathrm{Fe}, \mathrm{Ni}, \mathrm{Pb}, \mathrm{V}$ and $\mathrm{Zn}$, by ICP-AES, with a precision of $20 \%$ for As and $10 \%$ for the other elements (Instituto Geológico e Mineiro 1988). Tin and $\mathrm{W}$ were analysed by X-ray fluorescence spectrometry (XRF); the high stability of the XRF system generally allows these analyses with high precision. Tin and $\mathrm{W}$ were obtained with a precision of $10 \%$ (0.05 ppb) (Antunes et al. 2002; Instituto Geológico e Mineiro 1988).

Spatial modelling

The spatial characterization of PTE distribution was performed through a four-step approach:

(1) Principal component analysis (PCA) for dimensionality reduction and for variable association evaluation. PCA is one of the most important multivariate statistical methods widely used for data preprocessing and dimension reduction. The space of analysis is reduced by a construction of synthesis variables held by PCA. The aim of PCA is to reduce data dimensionality while preserving, at the same time, the withinvariability structure (variance-covariance) (e.g. Zuo et al. 2016). The analysis starts with $p$ random attributes, $\mathrm{X} 1, \mathrm{X} 2, \ldots, \mathrm{Xp}$, where no assumption of multivariate normality is required. The axes of the constant ellipsoids correspond to the new synthesis variables, the principal components. A Spearman correlationbased method (aiming at the reduction of the outliers' weight) was used to identify features or variations within the datasets by highlighting their similarities and differences. For computation, XIStat 2013.1.01 software was used (https://www.xlstat.com/en/).

(2) Structural analysis-experimental variograms were computed and theoretical models fitted (Matheron 1971; Journel and Huijbregts 1978; Gringarten and Deutsch 2001). For computation, SpaceStat V. 4.0-.18. software was used (https://www.biomedware.com/).

The variogram is a vector function used to calculate the spatial variability of regionalized variables defined by the following equation (Matheron 1971; Journel and Huijbregts 1978):

$\gamma=\frac{1}{2 N(h)} \sum_{2 N(h)}^{N(h)}\left[Z\left(x_{i}\right)-Z\left(x_{i}+h\right)\right]^{2}$.

Its argument is $h$ (distance) where $Z\left(x_{i}\right)$ and $Z\left(x_{i}+h\right)$ are the numerical values of the observed variable at points $x_{i}$, and $x_{i}+h$. The number of forming pairs for an $h$ distance is $N(h)$. Thus, it is the median value of the square of the differences between all pairs of points existing in the geometric field spaced at an $h$ distance. The graphic study of the obtained variograms provides an overview of the spatial structure of the variable. One of the parameters that provides such information is the nugget effect $\left(C_{\mathrm{o}}\right)$, which shows the behaviour at the origin. The other two parameters are the sill $\left(C_{1}\right)$ and the amplitude (a) which define, correspondingly, the inertia used in the interpolation process and the influence radius of the variable.

(3) Ordinary kriging (OK) algorithm was used for spatial interpolation aiming to predict the variables' values at any arbitrary spatial location within the study region and, so, compute content maps for the considered attributes $\left(\mathrm{CD}_{\mathrm{F} 1} ; \mathrm{CD}_{\mathrm{F} 2} ; \mathrm{CD}_{\mathrm{F} 3} ; \mathrm{CF}_{\mathrm{W}}\right.$ and $\left.\mathrm{CF}_{\mathrm{Cr}}\right)$. It is noteworthy that geostatistics are a reference approach for the characterization of environmental hazards where the data available are typically scarce. The primary application of geostatistics has been the estimation and mapping of environmental attributes in unsampled areas where kriging is a generic name for a set of generalized least-squares regression algorithms. Ordinary kriging (OK) accounts for local fluctuations of the mean by limiting the field of stationary of the mean to the local neighbourhood (Goovaerts 1997). For the computation, the SpaceStat Software V. 4.0.18, Biomedware, was used (Albuquerque et al. 2014).

(4) To reinforce the obtained findings of the last section, a Local G clustering was conducted to measure the degree of association resulting from the concentration of weighted points (or region represented by a weighted point) and all other weighted points (Albuquerque et al. 2017), included within a radius of distance 
from the original weighted point. Consider a given zone subdivided into $n$ regions, $I=1$, $2, \ldots, n$, where each neighbourhood is identified with a point whose cartesian coordinates are known. Each $i$ has associated with it a value $x$ (a weight) taken from a variable $X$. The variable holds a natural origin and it is positive. The $G(i)$ statistic developed below allows for tests of hypotheses concerning the spatial concentration of the sum of $x$ values associated with the $j$ points within $d$ of the $i$ th point. The following statistic is obtained:

$G_{i}(d)=\frac{\sum_{j=1}^{n} W_{i j}(d) X_{i}}{\sum_{j}^{n} x_{j}}$,

where Wij is a symmetric one/zero spatial weight matrix with ones for all links defined as being within distance $d$ of a given $i$; all other links are zero, including the link of point $i$ to itself. The numerator is the sum of all $x j$ within $d$ of $i$, but not including $x i$. The denominator is the sum of all $x j$, excluding $x i$ (Getis and Ord 1992).

\section{Results and discussion}

\section{Descriptive statistics}

The range, median and standard deviation of PTE concentrations in the stream sediments of Monfortinho are shown in Table 1. Stream sediments exhibit a large gap in the concentration values, in almost all elements, showing values up to $48,000 \mathrm{mg} / \mathrm{kg}$ of Fe, $750 \mathrm{mg} / \mathrm{kg}$ of $\mathrm{Ba}, 464 \mathrm{mg} / \mathrm{kg}$ of Cr, $202 \mathrm{mg} / \mathrm{kg}$ of $\mathrm{Zn}$ and $313 \mathrm{mg} / \mathrm{kg}$ of $\mathrm{V}$, indicating a geogenic and mining influence. The higher Fe content probably is due to Fe-oxyhydroxides which retain different metals and metalloids (e.g. Neiva et al. 2014; Antunes et al. 2016; Carvalho et al. 2016).

The variance in the stream sediment PTEs' contents may be viewed in the following box plots (Fig. 2), where the $Y$ axis represents the PTEs' concentration values. The plots bring forward the non-outlier limits, corresponding to the upper and the lower quartiles, within 1.5 times the interquartile amplitude.

Tin, As, W and Cd show severe outliers (Fig. 2). The presence of high amounts of $\mathrm{Fe}$ (Table 1) indicates a clear association with Fe-oxy and
Table $1 \mathrm{Fe}(\%)$ and PTE contents $(\mathrm{mg} / \mathrm{kg})$ in stream sediments

\begin{tabular}{llllc}
\hline & Minimum & Maximum & Median & SD \\
\hline $\mathrm{Fe}$ & 1.1 & 4.8 & 2.8 & 0.81 \\
$\mathrm{Ba}$ & 95 & 750 & 291 & 103.1 \\
$\mathrm{Cu}$ & 5 & 64 & 18.0 & 6.25 \\
$\mathrm{Cr}$ & 125 & 464 & 238 & 64.8 \\
$\mathrm{~B}$ & 5 & 37 & 20 & 6.4 \\
$\mathrm{Zn}$ & 16 & 202 & 57 & 27.1 \\
$\mathrm{~Pb}$ & 5 & 90 & 14 & 8.2 \\
$\mathrm{Sn}$ & - & 25 & 0.5 & 3.7 \\
$\mathrm{~V}$ & 21 & 313 & 65 & 29.9 \\
$\mathrm{Ni}$ & 11 & 42 & 24 & 6.8 \\
$\mathrm{As}$ & 10 & 44 & 10 & 6.1 \\
$\mathrm{~W}$ & - & 8 & 1.6 & 1.1 \\
$\mathrm{Cd}$ & 0.5 & 1.0 & 0.5 & 0.08 \\
$\mathrm{~N}$ & 271 & & & \\
\hline
\end{tabular}

$N$ number of samples, - below the detection limit

hydroxides which are common in stream sediments (e.g. Holmström and Öhlander 2001; Antunes et al. 2014; 2016; Neiva et al. 2016). Moreover, extreme values observed for $\mathrm{Ba}, \mathrm{Cu}, \mathrm{Zn}, \mathrm{Pb}, \mathrm{Sn}, \mathrm{As}, \mathrm{W}$ and $\mathrm{Cd}$ point out to the $\mathrm{Au}, \mathrm{Sn}-\mathrm{W}$ and $\mathrm{Ba}-\mathrm{Zn}$ mineralizations occurring around the study area, as these are responsible for their content in the stream sediments (e.g., Antunes et al. 2002; Jordan et al. 2007; Antunes et al. 2014). Boron and V contents in stream sediments may be associated with a geogenic origin, joined to the predominant lithologies occurring in the region.

Contamination risk evaluation

Several international methods for PTE stream sediment content evaluation are available in the literature, the remarkable ones being the contamination factor $(\mathrm{CF})$, the contamination degree (CD), the enrichment factor (EF), the geoaccumulation index (IGeo), the potential ecological risk index (PERI) and the G2met index (e.g. Håkanson 1980; Wenyl et al. 1997; Verca and Dolenec 2005; Karydas et al. 2015).

The CF was used to assess the enrichment degree of a PTE concentration and the potential toxicity index (RI) of stream sediments from the influence of the mine (Håkanson 1980; Sutherland 2000; Andrew and Sutherland 2004). 
Fig. 2 Box plots for the PTE content distribution in the collected stream sediment samples. $\mathrm{X}$-median; 25-75\%;

- minimum/maximum; o-outlier

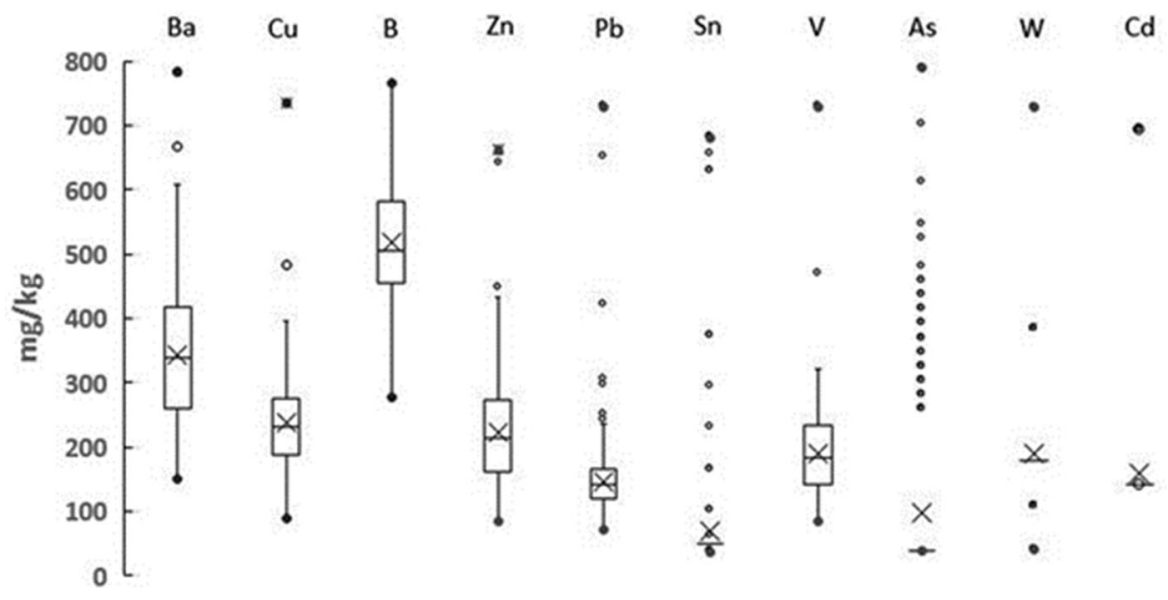

The CF spatial distribution for each PTE resulted from the relation between the concentration value of the considered element $\left(C_{i}\right)$ and a reference value of the element $\left(C_{\mathrm{b}}\right)$ (Sutherland 2000). The reference values included background concentration for stream sediments of Portugal. The Portuguese background values, from FOREGS Geochemical Atlas of Europe, are as follows: $\mathrm{Fe}=2.45 \%, \mathrm{Ba}=68 \mathrm{ppm}, \mathrm{Cu}=22$ ppm, $\mathrm{Cr}=23$ ppm; $\mathrm{B}=2 \mathrm{ppm} ; \mathrm{Zn}=74 \mathrm{ppm}, \mathrm{Pb}=$ $19 \mathrm{ppm}, \mathrm{V}=26 \mathrm{ppm}, \mathrm{Ni}=19 \mathrm{ppm} ; \mathrm{As}=9.0 \mathrm{ppm}$, $\mathrm{W}=1.0 \mathrm{ppm}, \mathrm{Cd}=0.2 \mathrm{ppm}$ (Ferreira 2000) and Sn $=2.25 \mathrm{ppm}$ (Salminen et al. 2005). The minimum, maximum and median stream sediment contamination factors of the selected PTE are presented in Table 2.

Most of the PTE exhibit a moderate contamination degree. However, $\mathrm{Ba}, \mathrm{Cr}$ and $\mathrm{B}$ show high and very high values for the contamination factor index (Table 2). The median CF values, considering the studied attributes, are as follows: $\mathrm{Cr}>\mathrm{B}>\mathrm{Ba}>$ $\mathrm{V}=\mathrm{Cd}>\mathrm{W}>\mathrm{Ni}>\mathrm{As}=\mathrm{Fe}>\mathrm{Pb}>\mathrm{Cu}=\mathrm{Zn}>$

Sn (Table 2), which is explained by the former mining activity in the region. Over $50 \%$ of the collected samples show moderate values for the contamination factor index: iron (83\%), $\mathrm{Cu}(76 \%)$, $\mathrm{Ag}(98 \%), \mathrm{Pb}(52 \%), \mathrm{V}(68 \%)$, As (82\%), W (63\%) and $\mathrm{Cd}(97 \%), \mathrm{Ba}(60 \%), \mathrm{Cr}(100 \%)$ and $\mathrm{B}(94 \%)$ (Fig. 3).

The contamination degree (CD) is the result of the total of all the $\mathrm{CF}$ and was reclassified accordingly to the number of the considered PTE (13 elements) (Table 2). The CD values in the Monfortinho stream sediments range from 24 up to 61 , corresponding to a moderate $(55 \%)$ to a high $(44 \%)$ contamination degree, respectively.

The CF values may suggest a source in PTE in the neighbourhood, but cannot indicate their chemical action or their biological availability (Guo et al. 2010). The potential ecological risk index $\left(\mathrm{E}_{f}^{i}\right)$ is a simple and a relative shortcut index, which not only reflects the single impact of metals on the ecological environment, but also combines the environmental chemistry, biological toxicology and ecology (e.g. Hong et al. 2004; Qinna et al. 2005). This factor is computed using the contamination factor $\left(\mathrm{C}_{f}^{i}\right)$ of the element and the coefficient response of the metal toxicity $\left(\mathrm{T}_{f}^{i}\right)$, suggesting that the hazard for human and aquatic ecosystems is a consequence of its toxicity and its ecological sensitivity (Guo et al. 2010). The applied coefficients $\left(\mathrm{T}_{f}^{i}\right)$ were: $\mathrm{Cd}=30 ; \mathrm{As}=10 ; \mathrm{Cu}=\mathrm{Pb}=$ $\mathrm{Ni}=5 ; \mathrm{Cr}=2$ and $\mathrm{Zn}=1$ (Qinna et al. 2005).

The potential ecological risk $\left(\mathrm{E}_{f}^{i}\right)$ and potential toxicity response index (RI) values are shown in Table 3.

The median values for $\mathrm{Fe}, \mathrm{Cu}, \mathrm{Cr}, \mathrm{As}$ and $\mathrm{Ni}$ (Table 4) are higher than those recorded in FOREGS-Geochemical Atlas of Europe (Salminen et al. 2005).

Multivariate statistics

In the case study considered, PCA results reveal the existence of three groups (Fig. 4): (a) a first group formed by $\mathrm{Fe}, \mathrm{Ni}, \mathrm{Ba}, \mathrm{Cu}, \mathrm{B}, \mathrm{Zn}$ and $\mathrm{V}$, which is a typical PTE association; (b) a second group composed of $\mathrm{Sn}$ and $\mathrm{Cd}$; (c) a third group representing $\mathrm{Pb}$ and $\mathrm{As}$. 
Table 2 Contamination factor (CF) and contamination degree (CD) of selected PTE in stream sediments

\begin{tabular}{|c|c|c|c|c|c|c|c|}
\hline & Minimum & Maximum & Median & & Minimum & Maximum & Median \\
\hline $\mathrm{Fe}$ & 1.1 & 4.8 & 2.3 & $\mathrm{Sn}^{\mathrm{a}}$ & - & 25 & 0.5 \\
\hline $\mathrm{CF}$ & 0.4 & 2.0 & 1.1 & $\mathrm{CF}$ & 0 & 11.1 & 0.2 \\
\hline $\mathrm{Ba}$ & 95 & 750 & 291 & V & 21 & 313 & 65 \\
\hline $\mathrm{CF}$ & 1.4 & 11.0 & 4.3 & $\mathrm{CF}$ & 0.8 & 12.0 & 2.5 \\
\hline $\mathrm{Cu}$ & 5.0 & 64 & 18 & $\mathrm{Ni}$ & 11 & 42 & 24 \\
\hline $\mathrm{CF}$ & 0.2 & 2.9 & 0.8 & $\mathrm{CF}$ & 0.6 & 2.2 & 1.3 \\
\hline $\mathrm{Cr}$ & 125 & 464 & 238 & As & 10 & 44 & 10 \\
\hline $\mathrm{CF}$ & 5.4 & 20.2 & 10.3 & $\mathrm{CF}$ & 1.1 & 4.9 & 1.1 \\
\hline B & 5.0 & 37 & 20 & W & - & 8.0 & 1.6 \\
\hline $\mathrm{CF}$ & 2.5 & 18.5 & 10.0 & $\mathrm{CF}$ & 0.0 & 8.0 & 1.6 \\
\hline $\mathrm{Zn}$ & 16 & 202 & 57 & $\mathrm{Cd}$ & 0.5 & 1.0 & 0.5 \\
\hline $\mathrm{CF}$ & 0.2 & 2.7 & 0.8 & $\mathrm{CF}$ & 2.5 & 5 & 2.5 \\
\hline $\mathrm{Pb}$ & 5 & 90 & 14 & & & & \\
\hline $\mathrm{CF}$ & 0.4 & 6.4 & 1.0 & & & & \\
\hline $\mathrm{CD}$ & 24.0 & 61.1 & 38.6 & & & & \\
\hline
\end{tabular}

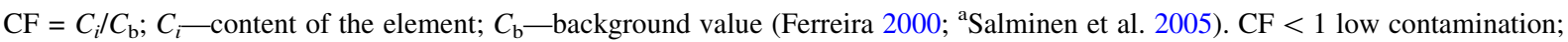
$1<\mathrm{CF}<3$ moderate contamination; $3<\mathrm{CF}<6$ high contamination; $\mathrm{CF}>6$ very high contamination. $\mathrm{CD}=\Sigma \mathrm{CF}$ : $\mathrm{CD}<13$ low contamination degree; $13<\mathrm{CD}<26$ moderate contamination degree; $26<\mathrm{CD}<39$ high contamination degree; $\mathrm{CD}>39$ very high contamination degree

Fig. 3 Percentage of contamination factor (CFs) classes in the area

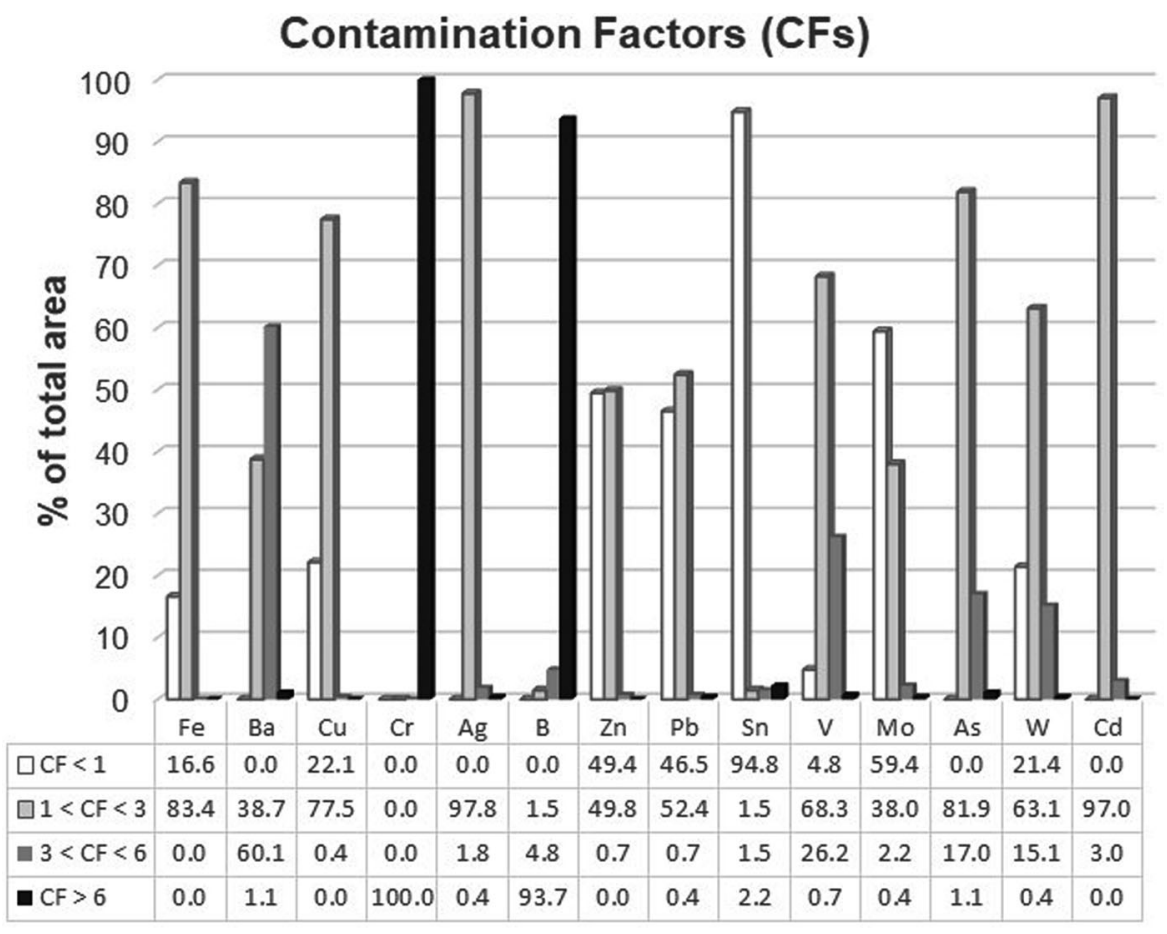


Table 3 Potential ecological risk index $\left(\mathrm{E}_{f}^{i}\right)$ and potential toxicity index (RI) of the selected PTE in stream sediments

\begin{tabular}{llll}
\hline & Minimum & Maximum & Median \\
\hline $\mathrm{E}_{f}^{i} \mathrm{Cu}$ & 1.8 & 22.9 & 6.4 \\
$\mathrm{E}_{f}^{i} \mathrm{Cr}$ & 11.9 & 44.2 & 22.7 \\
$\mathrm{E}_{f}^{i} \mathrm{Zn}$ & 0.3 & 3.4 & 1.0 \\
$\mathrm{E}_{f}^{i} \mathrm{~Pb}$ & 1.8 & 32.1 & 5.0 \\
$\mathrm{E}_{f}^{i} \mathrm{As}$ & 16.7 & 73.3 & 16.7 \\
$\mathrm{E}_{f}^{i} \mathrm{Cd}$ & 53.6 & 107.1 & 53.6 \\
$\mathrm{RI}$ & 92 & 189 & 107 \\
\hline
\end{tabular}

Ecological risk index: $\mathrm{E}_{f}^{i}=\mathrm{C}_{f}^{i} * \mathrm{~T}_{\mathrm{f}}^{\mathrm{i}} ; \mathrm{C}_{f}^{i}=\mathrm{CF}$ coefficient to the element; $\mathrm{T}_{\mathrm{f}}^{\mathrm{i}}-$ response coefficient for the toxicity of the element. Ecological risk level: $\mathrm{E}_{f}^{i}<40$-low; $40 \leq \mathrm{E}_{f}^{i}<$ 80-moderate; $80 \leq \mathrm{E}_{f}^{i}<160$-high; $160 \leq E_{f}^{i}<320$-very high; $320 \leq \mathrm{E}_{f}^{i}$-serious; potential toxicity response index: $\mathrm{RI}=\Sigma \mathrm{E}_{f}^{i}$. Potential ecological risk level: $\mathrm{RI}<150$-low grade; $150 \leq \mathrm{RI}<300$ - moderate; $300 \leq \mathrm{RI}<600$ - severe; $600 \leq \mathrm{RI}$-serious

Tungsten and $\mathrm{Cr}$ show an independent behaviour indicating a different source of provenance. The performed PCAs allowed to conclude that it is possible to reach a fuller recognition of relevant pollutant associations on setting a dependence on weight between elements: those which increase or decrease proportionally tend to link together.

The contamination degree (CD) was then computed considering the identified associations and classified as follows: (1) $\mathrm{CD}_{\mathrm{F} 1}-\mathrm{Fe}, \mathrm{Ni}, \mathrm{Ba}, \mathrm{Cu}, \mathrm{B}, \mathrm{Zn}$ and $\mathrm{V}$; (2) $\mathrm{CD}_{\mathrm{F} 2}-\mathrm{Sn}$ and $\mathrm{Cd}$; (3) $\mathrm{CD}_{\mathrm{F} 3}-\mathrm{Pb}$ and As. For $\mathrm{W}$ and $\mathrm{Cr}$, the individual contamination factor $(\mathrm{CF})$ was used, as it recorded an independent behaviour $\left(\mathrm{CF}_{\mathrm{W}}\right.$ and
$\mathrm{CF}_{\mathrm{Cr}}$ ). These new attributes were defined as regionalized variables (Matheron 1971) and consequently additive by construction, since the mean value within a given observed support is equal to the arithmetic average of sample values, whatever the statistical distribution of the values. This guarantees that two samples with given profiles in the variable can be replaced by a new individual (Rivoirard 2005; Albuquerque et al. 2014). A subsequent geostatistical approach aiming at spatial hazard definition was employed in the definition of clusters for future monitoring.

\section{Structural evaluation}

The experimental variograms $\gamma(h)$ were computed and then fitted by a theoretical model, $\gamma(h)$ (Isaaks and Srivastava 1989). The adjusted parameters for the five attributes (Fig. 5) show that the obtained models are fairly fit. Indeed, all the attributes have nugget effect below $40 \%$ of the total variance for all the attributes. The error associated with the interpolation procedure, ordinary kriging $(\mathrm{OK})$, is therefore minimized.

The revealed isotropic structure of $\mathrm{CD}_{\mathrm{F} 2}, \mathrm{CD}_{\mathrm{F} 3}$ and $\mathrm{CF}_{\mathrm{W}}$ and the anisotropic structure fitted for $\mathrm{CD}_{\mathrm{F} 1}$ and $\mathrm{CF}_{\mathrm{Cr}}$ are noteworthy, showing an important variability along the $\mathrm{EW}$ direction for $\mathrm{Fe}, \mathrm{Ni}, \mathrm{Ba}, \mathrm{Cu}, \mathrm{B}, \mathrm{Zn}, \mathrm{V}$ and $\mathrm{Cr}$, which may be interpreted as an enrichment (accumulation) due to the lithology, mainly the metapelites and metagreywackes of the Cambrian schist-metagreywacke complex.
Table 4 Stream sediment concentration comparison for $\mathrm{Fe}(\%)$ and another PTE $(\mathrm{mg} / \mathrm{kg})$ between the Monfortinho area and geochemical Atlas of Europe

- Below the detection limit

\begin{tabular}{lllllrl}
\hline$(\mathrm{mg} / \mathrm{kg})$ & Minimum & Maximum & Median & Minimum & Maximum & Median \\
\hline $\mathrm{Fe}$ & 1.1 & 4.8 & 2.8 & 0.06 & 20 & 1.97 \\
$\mathrm{Cu}$ & 5 & 64 & 18 & 1 & 998 & 14 \\
$\mathrm{Cr}$ & 125 & 464 & 238 & 2 & 1750 & 21 \\
$\mathrm{Zn}$ & 16 & 202 & 57 & 7 & 11 & 60 \\
$\mathrm{~Pb}$ & 5 & 90 & 14 & $<3$ & 4880 & 14 \\
$\mathrm{Sn}$ & - & 25 & 0.5 & $<1$ & 188 & 2.25 \\
$\mathrm{As}$ & 10 & 44 & 10 & $<5$ & 231 & 6.0 \\
$\mathrm{~W}$ & - & 8 & 1.6 & $<0.05$ & 82 & 1.24 \\
$\mathrm{Ni}$ & 11 & 42 & 24 & 2 & 1200 & 16 \\
$\mathrm{Mn}$ & 63 & 1301 & 288 & 24 & 18,900 & 452 \\
$\mathrm{Co}$ & 5 & 18 & 5 & $<1$ & 245 & 8 \\
$\mathrm{U}$ & 0.2 & 4 & 0.8 & $<1$ & 98 & 2 \\
\hline
\end{tabular}




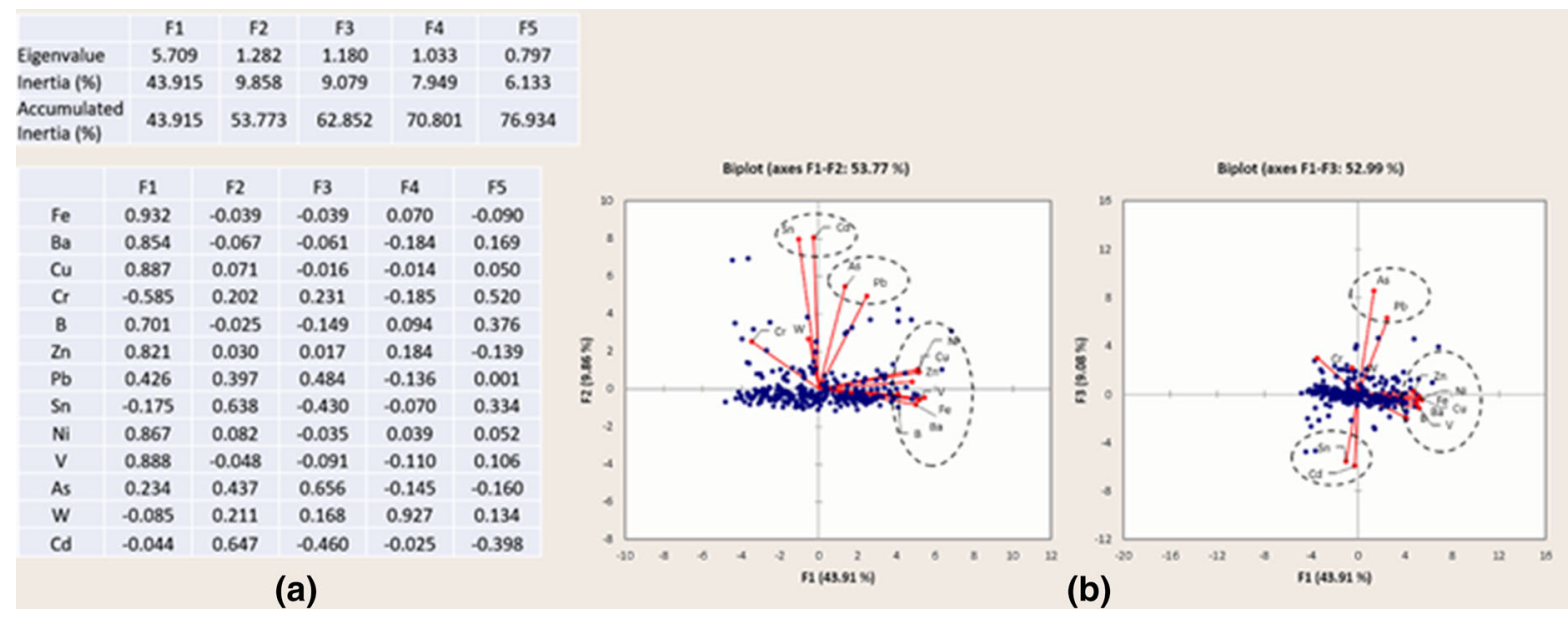

Fig. 4 Principal components analyses and definition of PTE associations. a Contributions and correlations between new principal components and the studied PTE; b first and second factorial plans with the attributes (red dots) and samples (blue dots) projected

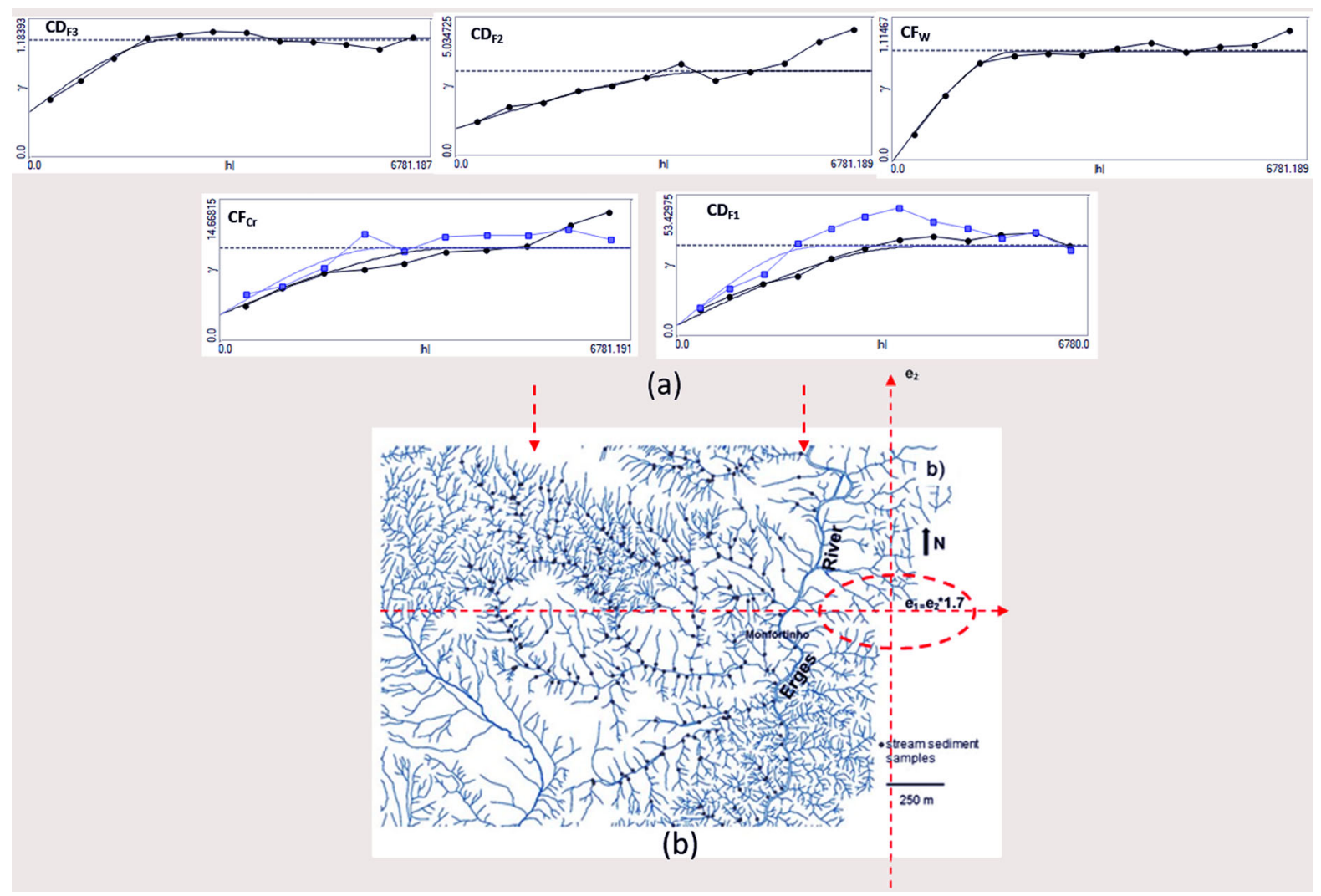

Fig. 5 Experimental variograms and fitted models. a Isotropic structure fitted for $\mathrm{CDF}_{2}, \mathrm{CDF}_{3}$ and $\mathrm{CDF}_{\mathrm{w}}$ and anisotropic ones for $\mathrm{CDF}_{1}$ and $\mathrm{CD}_{\mathrm{Cr}}$; $\mathbf{b}$ The anisotropic structures revealed the highest variability along the $\mathrm{W}-\mathrm{E}$ direction 

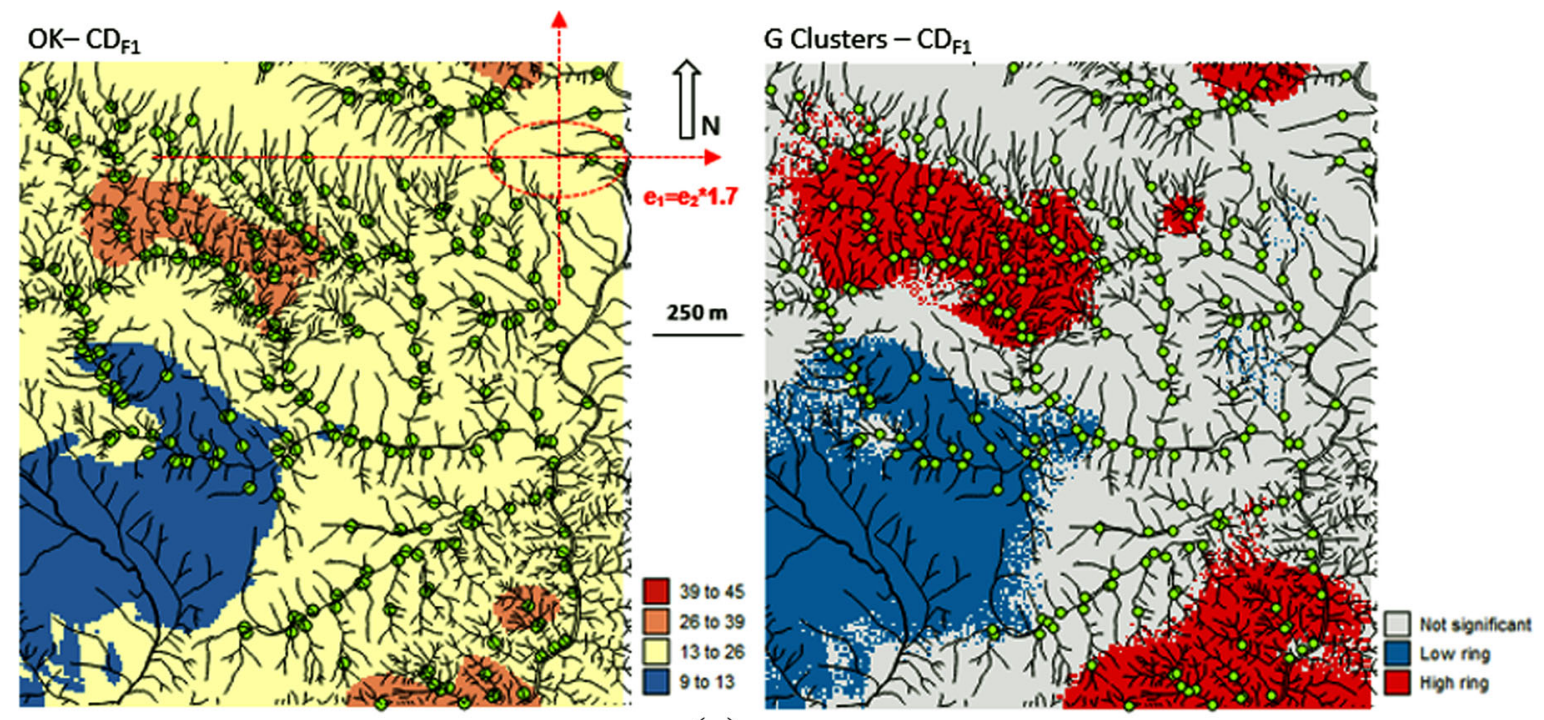

(a)

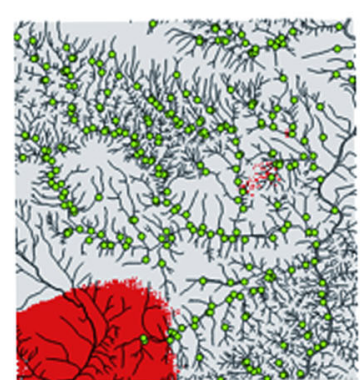

$\mathrm{G}$ Clusters $-\mathrm{CD}_{\mathrm{F} 2}$

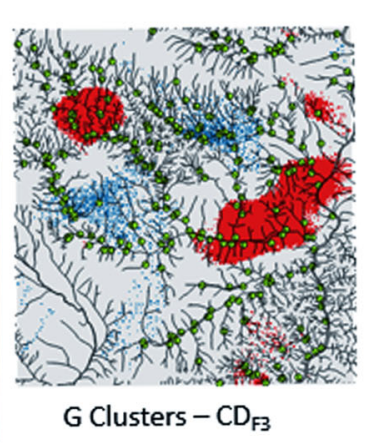

G Clusters $-\mathrm{CD}_{\mathrm{F3}}$
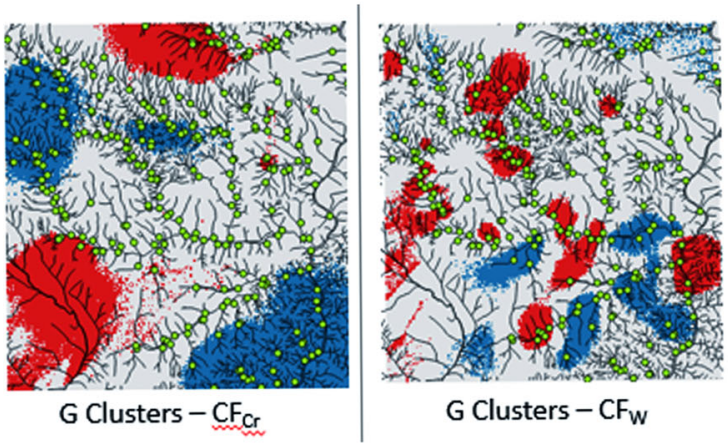

(b)

Fig. 6 a Distribution and $\mathrm{G}$ cluster map for $\mathrm{CD}_{\mathrm{F} 1}$; b G clusters for $\mathrm{CD}_{\mathrm{F} 2}, \mathrm{CD}_{\mathrm{F} 3}, \mathrm{CF}_{\mathrm{Cr}}$ and $\mathrm{CF}_{\mathrm{W}}$

Spatial analysis and modelling

When analysing the obtained outputs (Fig. 6), it is possible to acknowledge evident contrasts. Therefore, the estimated images obtained by OK and the spatial G clusters allow to determine regions of high significance for PTE enrichment and its potential origin.

Concerning the $\mathrm{CDF}_{1}(\mathrm{Fe}, \mathrm{Ni}, \mathrm{Ba}, \mathrm{Cu}, \mathrm{B}, \mathrm{Zn}$ and $\mathrm{V}$; Fig. 6), the high content observed, in the upper NW corner, is strongly associated with the local lithologies, as the observed high content in the SE corner may be explained by the Ba-Zn local mineralization as well as with the sedimentary gold along the Erges River banks. In similar geological sites, in the neighbourhood of Monfortinho, high contents in these factors were also found in stream sediments collected on schists (Antunes et al. 2002).

The observed $\mathrm{CDF}_{2}$ (Sn and $\mathrm{Cd}$ ) cluster (Fig. 6) may be related to the cassiterite exploitations in Segura region, which is located less than $20 \mathrm{~km}$ south of Monfortinho (Fig. 1a). Tin anomalies were also found in stream sediments from the Segura area, associated with $\mathrm{Sn}-\mathrm{W}$ mineralizations (Antunes et al. 2002). The $\mathrm{CDF}_{3}$ ( $\mathrm{Pb}$ and $\mathrm{As}$ ) shows two high rings, similar to the ones visible for $\mathrm{CDF}_{1}$ and overlapping the $\mathrm{Ba}-\mathrm{Zn}$ mineralization (barite and galena).

Chromium $\left(\mathrm{CF}_{\mathrm{Cr}}\right)$ shows an "inverse" distribution to $\mathrm{CD}_{\mathrm{F} 1}$ and $\mathrm{CD}_{\mathrm{F} 3}$, which is mainly explained by predominant schist mineralization. Finally, $\mathrm{W}\left(\mathrm{CF}_{\mathrm{W}}\right)$ shows an irregular distribution with higher 
concentration near the streams, since this element is easily "retained" in the sediments enriched in clay minerals.

\section{Conclusions}

A geochemical spatial distribution of potential toxic elements (PTE) in the stream sediments of the Monfortinho area (Central Portugal) was computed and the level of contamination determined using international evaluation methods, such as contamination factor $(\mathrm{CF})$, contamination degree $(\mathrm{CD})$, potential ecological risk index $\left(\mathrm{E}_{f}^{i}\right)$ and potential toxicity response Index (RI).

A total of 271 representative stream sediment samples were collected from the schist-metagreywacke complex. Stream sediments from the Monfortinho area show a large range of PTE contents, suggesting a geogenic and mine influence. Stream sediments presented a moderate contamination in most PTE, with although a high and very high contamination in $\mathrm{Ba}, \mathrm{Cr}$ and $\mathrm{B}$. Contamination degree index varies from moderate to high contamination degree, which is primarily linked to the old mineralizations of the Monfortinho area.

Uni- and multivariate statistic metodologies allowed the identification of redundant information and the identification of outliers where the space of subsequent analysis was assessed throughout the building of new synthesis variables-principal component analysis (PCA). Three groups emerged and the contamination degree index was calculated, respectively: $1 . \mathrm{CD}_{\mathrm{F} 1}-\mathrm{Fe}, \mathrm{Ni}, \mathrm{Ba}, \mathrm{Cu}, \mathrm{B}, \mathrm{Zn}$ and $\mathrm{V} ; \mathrm{CD}_{\mathrm{F} 2}-$ $\mathrm{Sn}$ and $\mathrm{Cd} ; \mathrm{CD}_{\mathrm{F} 3}-\mathrm{Pb}$ and $\mathrm{As}$. The contamination factor $(\mathrm{CF})$ was used for $\mathrm{W}$ and $\mathrm{Cr}$, as they revealed an independent behaviour.

Spatial modelling due to their significance in contamination forecast was performed and the construction of hazard maps allowed the definition of high significant PTE clusters and to assess their probable provenance and enrichment. The Monfortinho area is greatly affected by the mining legacy and the lithological environment. The NW and SE corners are highly enriched in $\mathrm{Fe}, \mathrm{Ni}, \mathrm{Ba}, \mathrm{Cu}, \mathrm{B}, \mathrm{Zn}, \mathrm{V}$, As and $\mathrm{Pb}$ due to local lithologies (NW corner) and the $\mathrm{Ba}-\mathrm{Zn}$ local mineralization along with the sedimentary gold enrichment in the Erges River banks (SE corner). The $\mathrm{Sn}$ and $\mathrm{Cd}$ cluster may be referred to the cassiterite exploitations in the Segura region $(20 \mathrm{~km}$ south Monfortinho). Finally, $\mathrm{Cr}$ shows an "inverse" distribution to the observed for Fe, Ni, Ba, Cu, B, Zn, V, As and $\mathrm{Pb}$, which may be explained by the predominant mineralization in the schist-metagreywacke complex. The irregular distribution of $\mathrm{W}$ with higher concentration near the streams could be explained by the low mobility of this element making its retention easy in the sediments enriched in clay minerals.

Future work requires an exhaustive collection of covariates, which will be used to enlighten PTE dynamics and, so, clarifying the main sources for PTE provenance as well as their enrichment through the study area. The multivariate geostatistical metodologies promoted the recognition and quantification of the anthropogenic impacts and consequently allowed the definition of adequate monitoring measures to focus the discussion on the human health effects in local communities.

Acknowledgements Our thanks are due to Prof. M.R. Machado Leite for the use of data on stream sediments from Instituto Geológico e Mineiro, S. Mamede de Infesta (Portugal). This work is co-funded by the European Union through the European Regional Development Fund, based on COMPETE 2020 (Programa Operacional da Competitividade e Internacionalização), project ICT (UID/GEO/04,683/2013) with reference POCI-01-0145-FEDER-007690 and national funds provided by Fundação para a Ciência e Tecnologia.

\section{References}

Abreu, M. M., Matias, M. J., Clara, M., Magalhães, F., \& Basto, M. J. (2008). Impacts on water, soil and plants from the abandoned Miguel Vacas copper mine, Portugal. Journal of Geochemical Exploration, 96, 161-170.

Albanese, S., Iavarro, P., Adamo, P., Lima, A., \& De Vivo, B. (2013). Assessment of the environmental conditions of the Sarno river basin (south Italy): a stream sediment approach. Environmental Geochemistry and Health, 35, 283-297.

Albuquerque, M. T. D., Antunes, I. M. H. R., Seco, M. F. M., Roque, N., \& Sanz, G. L. (2014). Uranium and arsenic spatial distribution in the Águeda watershed groundwater. Procedia Earth and Planetary Science, 8, 13-17.

Albuquerque, M. T. D., Gerassis, S., Sierra, C., Taboada, J., Martín, J. E., Antunes, I. M. H. R., et al. (2017). Developing a new Bayesian Risk Index for risk evaluation of soil contamination. Science of the Total Environment, 603-604, 167-177. https://doi.org/10.1016/j.scitotenv. 2017.06.068.

Alexakis, D. (2011). Diagnosis of stream sediment quality and assessment of toxic element contamination sources in East Attica, Greece. Environmental Earth Sciences, 63, 1369-1383. 
Andrew, S., \& Sutherland, R. A. (2004). Cu, Pb and Zn contamination in Nuuanu Watershed, Oahu, Hawaii. Science of the Total Environment, 324, 173-182.

Antunes, I. M. H. R., \& Albuquerque, M. T. D. (2013). Using indicator kriging for the evaluation of arsenic potential contamination in an abandoned mining area (Portugal). Science of the Total Environment, 442, 545-552.

Antunes, I. M. H. R., Albuquerque, M. T. D., \& Sanches, F. A. N. (2014). Spatial risk assessment related to abandoned mining activities: an environmental management tool. Environmental Earth Sciences. https://doi.org/10.1007/ s12665-014-3170-4.

Antunes, I. M. H. R., Gomes, M. E. P., Neiva, A. M. R., Carvalho, P. C. S., \& Santos, A. C. T. (2016). Potential risk assessment in stream sediments, soils and waters after remediation in an abandoned $\mathrm{W}>$ Sn mine (NE Portugal). Ecotoxicology Environmental Safety, 133, 135-145.

Antunes, I. M. H. R., Neiva, A. M. R., \& Silva, M. M. V. G. (2002). The mineralised veins and the impact of old mine workings on the environment at Segura, Central Portugal. Chemical Geology, 190(1-4), 417-431.

Antunes, I. M. H. R., Neiva, A. M. R., Silva, M. M. V. G., \& Corfu, F. (2009). The genesis of I- and S-type granitoid rocks of the Early Ordovician Oledo pluton, Central Iberian Zone (central Portugal). Lithos, 111(3/4), 168-185.

Baptista Neto, J. A., Smith, B. J., \& McAllister, J. J. (2000). Heavy metal concentrations in surface sediments in a near shore environmental, Jurujuba Sound, Southeast Brazil. Environmental Pollution, 109, 1-9.

Batata, C. (2006). Explorações mineiras antigas entre os rios Zêzere, Tejo e Ocreza. Atas do III Simpósio sobre Mineração e Metalurgia Históricas no Sudoeste Europeu, 21-23 de junho de 2005, Porto (pp. 67-77).

Bertin, C., \& Bourg, A. C. M. (1995). Trends in the heavy metal content $(\mathrm{Cd}, \mathrm{Pb}, \mathrm{Zn})$ of river sediments in the drainage basin of smelting activities. Water Research, 29(7), 1729-1736.

Carvalho, P. C. S., Neiva, A. M. R., Silva, M. M. V. G., \& Santos, A. C. T. (2016). Human health risks in a gold mining area with circum-neural drainage, central Portugal. Environmental Geochemistry and Health. https://doi.org/ 10.1007/s10653-016-9806-4.

Chapman, R. J., \& Mortensen, J. K. (2006). Application of microchemical characterization of placer gold grains to exploration for epithermal gold mineralization in regions of poor exposure. Journal of Geochemical Exploration, 91, $1-26$.

Chapman, P. M., \& Wang, F. Y. (1999). Appropriate applications of sediment quality values for metals and metalloids. Environment Science and Technology, 33, 3937-3941.

Chen, H., Chen, R., Teng, Y., \& Wu, J. (2016). Contamination characteristics, ecological risk and source identification of trace metals in sediments on the Le'an River (China). Ecotoxicology and Environmental Safety, 125, 82-85.

Darwish, M. A. G., \& Poellmann, H. (2010). Geochemical exploration for gold in the Nile valley Block (A) area, Wadi Allaqi, South Egypt. Chemie der Erde, 70, 353-362.

Dauvalter, V., \& Rognerud, S. (2001). Heavy metal pollution in sediments of the Pasvik river drainage. Chemosphere, 42, 9-18.
Ferreira, A. M. P. J. (2000). Dados geoquímicos de base de sedimentos fluviais de amostragem de baixa densidade de Portugal Continental: Estudo de factores de variação regional. Unpublished Ph.D. thesis, Univ. Aveiro, Portugal.

Ferreira da Silva, E., Serrano Pinto, L., Patinha, C., \& Cardoso Fonseca, E. (2004). Site-specific characterization of Castromil Brownfield area related to gold mining activities. Environmental Geochemistry and Health, 26, 13-25.

Fletcher, W. K. (1997). Stream sediment geochemistry in today's exploration world. In Gubins, A. G. (Ed.), Proceedings of exploration 97-4th decennial international conference on mineral exploration (pp. 249-260).

Getis, A., \& Ord, J. K. (1992). The Analysis of Spatial Association by Use of Distance Statistics. Geographical Analysis, 24, 189-206.

Gieré, R., Sidenko, N. V., \& Lazareva, E. V. (2003). The role of secondary minerals in controlling the migration of arsenic and metals from high sulphide wastes (Berikul gold mine, Siberia). Applied Geochemistry, 18(9), 1347-1359.

González-Fernández, B., Rodríguez-Valdés, E., Boente, C., Menéndez-Casares, E., Fernández-Braña, A., \& Gallego, J. R. (2018). Long-term ongoing impact of arsenic contamination on the environmental compartments of a former mining-metallurgy area. Science of the Total Environment, 610-611, 820-830.

Goovaerts, P. (1997). Geostatistics for Natural Resources Evaluation. Oxford: University Press.

Goovaerts, P., Albuquerque, T., \& Antunes, I. M. H. R. (2014). A spatial statistical approach for sedimentary gold exploration: A Portuguese case study. Mathematics of Planet Earth, Lecture Notes in Earth System Sciences. https://doi. org/10.1007/978-3-642-32408-6_119.

Goovaerts, P., Albuquerque, M. T. D., \& Antunes, I. M. H. R. (2016). A Multivariate geostatistical methodology to delineate areas of potential interest for future sedimentary gold exploration. Mathematical Geosciences. https://doi. org/10.1007/s11004-015-9632-8.

Gringarten, E., \& Deutsch, C. V. (2001). Teacher's aide variogram interpretation and modeling. Mathematical Geology, 33(4), 507-534.

Guo, W., Liu, X., Liu, Z., \& Li, G. (2010). Pollution and potential ecological risk evaluation of heavy metals in the sediments around Dongjiang Harbor, Tianjin. Procedia Environmental Science, 2, 729-736.

Håkanson, L. (1980). An Ecological Risk Index for aquatic pollution control-A sedimentological approach. Water Research, 14(8), 975-1001.

Holmström, H., \& Öhlander, B. (2001). Layers rich in Fe- and Mn-oxyhydroxides formed at the tailings-pond water interface, a possible trap for trace metals in flooded mine tailings. Journal of Geochemical Exploration, 74(1/3), 189-203.

Hong, H., Yajuan, Y., \& Xiaodong, W. (2004). Pollution of heavy metals in surface sediments from Huaihe River (Jiangsu Section) and its assessment of Potential Ecological Risk. Environmental Pollution Control, 26(3), 115-118.

Instituto Geológico e Mineiro. (1988). Reports from a prospecting project for tungsten, tin and associated 
minerals from Góis-Segura. Metallic mineral prospecting section (p. 10). Lisbon: Oporto.

Isaaks, E. H., \& Srivastava, R. M. (1989). An introduction to applied geostatistics (pp. 278-322). Oxford: University Press.

Jain, C. K., \& Sharma, M. K. (2001). Distribution of trace metals in the Hindon river system, India. Journal of Hydrology, 253, 81-90.

Jordan, C., Zhang, C., \& Higgins, A. (2007). Using GIS and statistics to study influences of geology on probability features of surface soil geochemistry in Northern Ireland. Journal of Geochemical Exploration, 93, 135-152.

Journel, A. G., \& Huijbregts, C. J. (1978). Mining geostatistics. San Diego: Academic Press.

Karydas, C. G., Tzoraki, O., \& Panagos, P. (2015). A new spatiotemporal risk index for heavy metals: application in cyprus. Water, 7(8), 4323-4342. https://doi.org/10.3390/ w7084323.

Matheron, G. (1971). The theory of regionalized variables and its applications. Les Cahiers du Centre de Morphologie Mathématique, no. 5, Ecole des Mines de Paris.

McInnes, M., Greenough, J. D., Fryer, B. J., \& Wells, R. (2008). Trace elements in native gold by solution IPC-MS442 and their use in mineral exploration: a British Columbia example. Applied Geochemistry, 23, 1076-1085.

Neiva, A. M. R., Antunes, I. M. H. R., Carvalho, P. C. S., \& Santos, A. C. T. (2016). Uranium and arsenic contamination in the former Mondego Sul uranium mine area, Central Portugal. Journal of Geochemical Exploration, 162, 1-15.

Neiva, A. M. R., Carvalho, P. C. S., Antunes, I. M. H. R., Santos, A. C. T., \& Cabral-Pinto, M. M. S. (2015). Spatial and temporal variability of surface water and groundwater before and after remediation of a Portuguese uranium mine area. Chemie der Erde - Geochemistry, 75(3), 345-356.

Neiva, A. M. R., Carvalho, P. C. S., Antunes, I. M. H. R., Silva, M. M. V. G., Santos, A. C. T., Pinto, M. M. S. C., et al. (2014). Contaminated waters, stream sediments and soils close to the Pinhal do Souto abandoned uranium mine, central Portugal. Journal of Geochemical Exploration, 136, 102-117.

Oliveira, J. T., Pereira, E., Ramalho, M., Antunes, M. T., \& Monteiro, J. H. (1992). Carta Geológica de Portugal na escala 1/500 000 ( $5^{\mathrm{a}}$ ed.). Lisboa: Serviços Geológicos de Portugal.

Plant, J., Smith, D., Smith, B., \& Williams, L. (2001). Environmental geochemistry at the global scale. Applied Geochemistry, 16, 1291-1308.

Qinna, Z., Qixin, X., \& Kai, Y. (2005). Application of Potential Ecological Risk Index in soil pollution of typical polluting industries. Journal Eastchina Normal University (Natural Science), 1, 110-115.

Rivoirard, J. (2005). Concepts and methods of geostatistics. Space, Structure and randomness. In M. Bilodeau, F. Meyer, \& M. Schmitt (Eds.), Contributions in honor of Georges Matheron in the fields of geostatistics, random sets and mathematical morphology. ISBN: 978-0-38720331-7.

Romic, D., Romic, M., Zovko, M., Bakic, H., \& Ondrasek, G. (2012). Trace metals in the coastal soils developed from estuarine foodplain sediments in the Croatian Mediterranean region. Environmental Geochemistry and Health. https://doi.org/10.1007/s10653-012-9449-z.

Salminen, R., Batista, M. J., Bidovec, M., Demetriades, A., De Vivo, B., De Vos, W., Duris, M., et al. (2005). FOREGS Geochemical Atlas of Europe. Methodology and maps (Part 1-526 pp. and Part 2-690 pp).

Santos, A., Alonso, E., Callejon, M., \& Jimenez, J. C. (2002). Heavy metal content and speciation in groundwater of the Guadiamar river basin. Chemosphere, 48, 279-285.

Santos Oliveira, J. M., Pedrosa, M. Y., Canto Machado, M. J., \& Rochas Silva, J. (1998). Impacte ambiental provocado pela actividade mineira. Caracterização da situação junto da Mina de Jales, avaliação dos riscos e medidas de reabilitação. Actas do V Congresso Nacional de Geologia, 84(2), 74-77.

Schwarz, S. (1933). Arqueologia mineira-Extrato dum Relatório Acerca de Pesquisas de Ouro, no Concelho de Idanhaa-Nova, Apresentado em Março de 1933, pela Empresa Mineira-Metalúrgica, Limitada. Boletim de Minas (pp. 35-38).

Singh, M., Ansari, A. A., Müller, G., \& Singh, I. B. (1997). Heavy metals in freshly deposited sediments of the Gomati river (a tributary of the Ganga river): Effects on human activities. Environmental Geology, 29, 246-252.

Sutherland, R. A. (2000). Bed sediment-associated trace metals in an urban stream. Oahu, Hawaii, Environmental Geology, 39, 611-627.

Townley, B. K., Hérail, G., Maksaev, V., Palacios, C., de Parseval, P., Sepulveda, F., et al. (2003). Gold grain morphology and composition as an exploration tool: Application to gold exploration in covered areas. Geochemical Exploration Environmental Analytical, 3, 29-38.

Tzoraki, O., Karaouzas, I., Patrolecco, L., Skoulikidis, N., \& Nikolaidis, N. (2015). Polycyclic Aromatic Hydrocarbons (PAHs) and heavy metal occurrence in bed sediments of a Temporary River. Journal of Water, Air and Soil, 226, 421. https://doi.org/10.1007/s11270-015-2671-4.

Verca, P., \& Dolenec, T. (2005). Geochemical estimation of copper contamination in the Healing Mud from Makirina Bay, Central Adriatic. Environmental International, 31(1), 53-61.

Wenyl, H., Fengru, H., \& Jingsheng, C. (1997). Comparative study of assessment method for river particulate heavy metal pollution. Science Geography Sinca, 17(1), 81-86.

Woitke, P., Wellmitz, J., Helm, D., Kube, P., Lepom, P., \& Litheraty, P. (2003). Analysis and assessment of heavy metal pollution in suspended solids and sediments of the river Danube. Chemosphere, 51, 633-642.

Zheng, N., Wang, Q. C., Liang, Z. Z., \& Zheng, D. M. (2008). Characterization of heavy metal concentrations in the sediments of three freshwater rivers in Huludao City, Northeast China. Environmental Pollution, 154, 135-142.

Zuo, R., Carranza, E. J. M., \& Wang, J. (2016). Spatial analysis and visualization of exploration geochemical data. EarthScience Reviews, 158, 9-18. https://doi.org/10.1016/j. earscirev.2016.04.006. 